\title{
Post-colonial Interpretation of the Property in Jane Eyre
}

\author{
Wang Xiteng \\ School of Foreign Language Studies, Guangzhou University \\ Email: 784767600@qq.com Tel: +86-18588850115
}

Keywords: possession; post-colonial; Jane Eyre

\begin{abstract}
As a world-renowned book that influences long-lasting ambitions, Jane Eyre has been favored by Chinese literary theory critics since its birth. Along with the development of post-colonial theory, after the 1980s, the domestic academic circles conducted a related post-colonial interpretation of Jane Eyre from multiple dimensions, but few studies have carried out an in-depth exploration of property issues in literary works. This paper is based on the analysis of the post-colonial meaning of the relevant property in the novel, and exposes the postcolonial nature of the unclear property in many literary works of the $19^{\text {th }}$ century.
\end{abstract}

\section{Domestic Post-colonial Interpretation of Jane Eyre}

As one of the classic works of world literature, the Chinese academic circles have long studied the renowned novel Jane Eyre. In the 1917 Women's Magazine, the article "Tai Xi Female Novelist" first introduced the Bronte sisters to Chinese readers. With the rise and fall of literary theory in the 20th century, Chinese scholars and readers praised the words. And pointed out its many shortcomings. Nowadays, in the Chinese online search keyword "Jane Eyre", there are 1857 related papers from 1979 to 2011. Most of them are researched and analyzed from the perspectives of literary theory such as feminism, post-colonialism, Marxism, and Christian cultural studies and narratology. In the late 1980s and early 1990s, the introduction of postcolonial theory in domestic academic circles and the interpretation of post-colonialization of Jane Eyre had a clear causal relationship. As early as 1986, Spivak pointed out in her book, "If we don't remember that imperialism, as the mission of the British society, was once a key part of Britain's construction of its culture, then we have no way of interpreting British literature in the 10th century. The function of literature in cultural expression cannot be ignored. In the 19th century Britain In the reading of literature, these two obvious 'facts' have been ignored, and it itself proves the continued success of imperialism that is constantly evolving into a modern form,"[1] In 2000, Zhang Zhongzai pointed out in "The Trip to India: The Disharmonious Double Voice: Anti-colonial Discourse and Colonial Discourse", starting from the "Robinson Crusoe" in the $18^{\text {th }}$ century, the British people involved in the writer should be overseas. Adventures, business, missions and other activities are more or less imprinted with racism. "The British generation of literati is more or less inherited the empire or colonial consciousness in this text reference tradition, and in many Under the construction of the text saturated with colonial discourse, it formed a collective consciousness that was sometimes not realized by the writer himself; this collective consciousness constructed countless colonial images and formed a white discourse of a colonial country." [2]

Even though many writers have their own anti-colonial tendency, "both British writers and colonial writers maintain the colonial rule of the empire to varying degrees, and their narratives fail to transcend the colonial perspective."[3] Some researchers have combined · After reading the interpretation of Rees's "The Sea of the Sea" and "Jane Eyre", it is basically agreed that "Jane Eyre" written in the prosperous period of the colonial empire inevitably permeates a strong sense of imperialism. They believe that Charlotte Grande clearly demonstrates the superiority of Westerners through the description of the demonization, materialization, and marginalization of mad women. From the perspective of post-colonial review of Jane Eyre, it is not so much that it sacrifices the "mad woman" to complete the high-level rational image and pure love of Jane Eyre. It is better to consciously deprive the mad woman of the right to speak and construct it. It represents the central voice of imperialism. It can be said that domestic academic circles have carried out in-depth 
excavation and discovery in the comparative reference of foreign "Jane Eyre" research, but in the post-colonial perspective, there are still many places for further study. For example, two property issues that play an important role in the work.

\section{Post-colonial Analysis of Bertha's Property}

The $19^{\text {th }}$ century was the heyday of Britain. In 1180, the merger of Ireland, the establishment of the "United Kingdom of Great Britain and Ireland"; in 1815 "Waterloo" defeated Napoleon, determined its dominance in Europe. In 1837, the Victorian era opened. Ten years later, Charlotte published the world-famous book, Jane Eyre. Based on the background of this era, it is not difficult to understand that all kinds of novels in the $19^{\text {th }}$ century, such as Jane Eyre, are full of various colonial and commercial operations. The wealth plundered from the colonies in various ways flowed into the pockets of British citizens, and Bertha's hometown, the West Indies, was one of the many colonies of the year.

In the descriptions of Bertha's parents, such as "His (Rochester's father) old friend Mr. Mason is a plantation owner and a businessman in the West Indies. He is convinced that his property is again More reliable."[4] ${ }^{306}$ Another example is that Rochester, who is offered by Bertha's brother in the church, has testimony of bigamy: “...with my sister, businessman Jonas Mason and his wife Creole (born in Latin American European descent, or A mixed-race with a black or Indian), the daughter of Antoinette Mason, Bertha Antoinette Mason, married in the XX Church in the Spanish city of Jamaica...".[4] $]^{322}$ It is not difficult to see that Bertha's father is also an Englishman, and her mother is likely to be a local Latino. As we clarify these relationships, we believe that many questions have arisen. Is Joshua's father, Jonas Mason, a young man who went to the West Indies to carry out slave trade and slavery for plantation work? If not, how does he rely on so many wealth? Why did he marry Bertha's mother, a mixed-race non-European woman? Is Bertha's mother crazy before Bertha's parents get married? Is Rochester the revival of Bertha's father (Bertha's father sneaked into the property of his mother's family and married his mother, and then maddened Bertha's mother because of cultural differences and imperialism?) Is Bertha's madness related to his father? This series of problems cannot be explained by the shortcomings of today's prototype materials. But what we can be sure of is that the 30,000-pound dowry provided by Bertha's father must be the wealth that was found through colonial means such as plantations. What is the fortune of 30,000 pounds? In 1816, the United Kingdom passed the "Gold Standard System Act", which recognized the use of gold as the currency standard to issue banknotes in the form of law. In 1821, the British officially adopted the gold standard, and the British pound became the standard currency unit of the United Kingdom, with 7.32238 grams of pure gold per pound. If the current futures gold is about 385 yuan a gram, then the first pound in the early 19th century is equivalent to 2800 yuan now, that 30,000 pounds are about equal to the current 84 million yuan.

In the novel, Rochester, who is in the second place in the family, marries Jonas Mason's daughter under the arrangement of his old father who loves money. The money he got from the other party has become the life of Rochester. get on. In other words, the colony became the "safe place" for the rich life of Great Britain. Such arguments are also reflected in the legacy of his uncle who is inherited by Jane Eyre.

However, as a typical representative of the colonizer, Rochester did not appreciate the land of the "other" who brought him a lot of wealth. On the contrary, he had nowhere to exclude people from the environment there, shouting "That kind of life "is simply hell" $[4]^{324}$, even reaching "close to the edge of despair."[4] $]^{325}$ On the other hand, respect for the more advanced, more civilized, more glamorous Western civilization. "The lovely wind that blows from Europe is still whispering between the leaves that have become fresh. The Atlantic is freely and indulgently whistling. My long-lost heart, I heard this whistling sound stretched out, fill the boiling blood - my life is praying for renewal, my soul is eager to clear the nectar. I see the hope of resurrection - I feel that regeneration is possible." It is not advisable to despise or strongly reject Eastern culture in the form of colonial imperialism. But because of Rochester's own class and utilitarianism, he and Bertha are destined to be able to communicate on an equal cultural discourse. 


\section{Post-colonial analysis of the inheritance of Jane Eyre}

In the story, Jane Eyre unexpectedly inherited the 20,000-pound legacy of his uncle in the Madras Islands. Madras is located in southeastern India for more than 300 years. In 1639, the British East India Company established a trading post on the north bank of the Guwum River, and in the following year, St. George Fort was built. Since then, the city has developed as a core. By 1652, Madras had been the UK's looting South Indian cotton textile and handicraft base. As overseas trade expanded, it became the capital of the British province of Madras. After 1801, the territory of Madras continued to expand westward and northward, dredging the harbor, developing railways, highways and canal traffic, and the city expanded, becoming the center of politics, economy, trade, and transportation in southern India. On the surface, his uncle is the wine agent of Bertha's brother Mason, but in fact, he frequently travels to and from the slave trade routes of the West Indies, the Madeiras, and the United Kingdom. Although the emergence of this heritage is a great joy. It not only solves the wealth problem of Jane Eyre, but also solves the problem of marginalized identity, so that she no longer "inferiority", but instead is equal to and even noble to Mr. Rochester. However, it is interesting to note that no matter whether Jane Eyre or St. John and his sister are facing this legacy, there is no word about the legitimacy of the estate.[5] That is to say, in their consciousness, all kinds of money that plundered the fat of the colonial people were legal and taken for granted. This is related to Horry Baba's post-colonial theory: "The goal of colonial discourse is to interpret the colonial people as a group of degenerate types based on ethnic archetypes so that they can conquer the colonists. Legalization, and then the establishment of management and education system." Thus, Jane Eyre is an unconscious "passive" colonizer in the Western imperialist colonial discourse system. As the image of the novel, Charlotte, the only miniaturization of the colored people in the novel is instrumentalized and rejected, which can better reflect the author's unconsciousness and expose the prevalence of British social colonialism.

What deserves our attention here is that compared with colonists such as Rochester, who have consciously related colonial experiences, such a colonialist is even more terrible. The concept of colonialism has been deeply rooted in the mind and hidden in culture. The imperialist colonial countries consciously achieved this goal through various means.

\section{Post-colonial Excavation of Property in Other $19^{\text {th }}$ century Novels}

In addition to the property of Jane Eyre, which is full of colonial copper smell, in the middle and late 18th century, throughout the 19th century, and even until the end of the colonial rule of the mid-twentieth century imperialism, from the works of Western novels and other genres. Being able to arbitrarily extract the "fruit" of colonial discourse. This collective unconscious did not realize that it was terrible until the disclosure of Orientalist researchers such as Said in the middle and late 20th century.

For example, in the works of the French writer Balzac, there is a clear manifestation. In his work "Human Comedy", important person Fu Teng- cold has designed to buy 200 blacks with 200,000 francs. "With this asset, I can earn three or four million in ten years." The days are like the little emperors." As in the "Old Man", almost every character revolves around the wealth that is searched through colonial means.

In Dickens's novels, there are also many sources of unknown origins, such as the axis of contradiction in "Bleak House", that is, the property of Mr. Jardis. Due to a bizarre will, almost no one can read it, and his descendants commit suicide, go crazy, etc. because they can't understand the will. But few people mentioned the source of this property.

As the Chinese scholar Mr. Wang Yuechuan said: "On the surface, the text is just the writing of the novel. It seems that there is no social political control. In fact, he has a deep connection with the power of desire, not just the conflict and the rule. The system is textualized and is the object of conflict between people.”[6] A large number of Western literary works require us to reinterpret and extract the "toxins" to make warnings and prevent them from continuing. There is a reason to believe that this is a necessary and positive process leading to "world literature." 


\section{References}

[1] Moore-Gilbert B., Stanton G., Maley W., Postcolonial Criticism, Published by Addison Wesley Longman Limited, 1997, p. 146.

[2] Zhongzai Zh.: "The Trip to India: The Double Harmony: Anti-colonial Discourse and Colonial Discourse", [J]. Foreign Literature, 2000, (3).

[3] Yanni L.: "The British Colonial and Post-colonial Novels of the 20th Century: A Perspective of the Sovereign States", [J]. Foreign Literature Studies. 2003, (4).

[4] Bronte C., Zhaolin Song, "Jane Love", [M]. China Books Publishing House, May 2005 edition, pp. 306, 322, 324, 325.

[5] Bhabba H. The Location of Culture, [M]. NewYork: Routledge, 1994, p. 34.

[6] Yuechuan W.: Post-colonialism and New Historicism, [M]. Jinan: Shandong Education Press, 1999, p. 51. 